Ivan IVANOVIĆ, Ph.D. ${ }^{1}$

E-mail: i.ivanovic@sf.bg.ac.rs

Nikola ČELAR, Ph.D. ${ }^{1}$

E-mail: n.celar@sf.bg.ac.rs

Vladimir ĐORIĆ, Ph.D. ${ }^{1}$

E-mail: v.djoric@sf.bg.ac.rs

Dragana PETROVIĆ, Ph.D ${ }^{1}$

E-mail: dragana.petrovic@sf.bg.ac.rs

${ }^{1}$ Faculty of Transport and Traffic Engineering

University of Belgrade

Vojvode Stepe 305, 11000, Belgrade, Serbia
Transport Engineering Original Scientific Paper Submitted: 30 June 2021 Accepted: 23 Aug. 2021

\title{
MODELLING THE IMPACT OF RAIN IN TRAFFIC ASSIGNMENT PROCEDURES
}

\begin{abstract}
The efficiency of urban transportation system is under the influence of weather conditions. It is necessary to incorporate these impacts into transport system analysis, in order to prepare adequate mitigation measures. Transport models are often used in different types of transport system analysis and forecasting of its future characteristics. This paper focuses on implementation of the impact of rain in transport modelling, particularly into a traffic assignment process as a part of a macroscopic transport model. This aspect of modelling is important because it can indicate parts of the network where this impact leads to a high volume/capacity ratio, which is a good input for defining mitigation measures. Commonly, transport models do not consider weather impacts in its standard procedures. The paper presents a methodology for calibrating volume-delay function in order to improve traffic assignment modelling in case of rain. The impact of different rain categories on capacity and free-flow speed was quantified and implemented in the volume-delay function. Special attention is given to the calibration of the part of volume-delay function for over-saturated traffic conditions. Calibration methodology is applicable for different types of volume-delay functions and presents a solid approach to incorporate weather conditions into common engineering practice.
\end{abstract}

\section{KEYWORDS}

rain impact; volume-delay function; transport model; traffic assignment.

\section{INTRODUCTION AND MOTIVATION}

Increase in population, car ownership, and economic activities, especially in urban areas, produced additional pressure on urban transportation systems [1]. There are also many other impacts which could significantly affect the efficiency of transport net- work such as: lack of multimodal and route alternatives, low accessibility, inability to apply modern technological solutions, etc. [2]. It is expected that climate characteristics and adverse weather will also affect the features of travel pattern and traveller behaviour especially due to the fact that they are becoming more frequent and intense.

In recent years, there has been an increasing number of studies exploring the impact of weather conditions on transportation system [3,4]. Today, the changes of weather conditions can be predicted with relatively high level of certainty, enabling easier modelling. Depending on climate and geographic zone there are different perceptions about what are good and what adverse weather conditions. But when it comes to transportation system users, ideal weather conditions (IWC) can be described as follows: no precipitation, dry roadway, visibility greater than $0.4 \mathrm{~km}$, wind speed lower than $16 \mathrm{~km} / \mathrm{h}$, and temperature above $10^{\circ} \mathrm{C}$ [5-7]. Any type of weather conditions which deviates from IWC and causes changes in driver and traveller behaviour and thus affect transportation system efficiency should be taken into account. Individual transportation system user adjusts its behaviour to new circumstances at local level and its individual reaction can affect the efficiency of the entire transport network [8]. The reduction of efficiency of infrastructure is reflected in the change in the level of service, degree of saturation, travel time, etc. It is often proposed that the impact of weather conditions and climate change should be included in planning and management of transport infrastructure as a mandatory prerequisite $[4,9]$. 
Researchers explored the impacts of adverse weather conditions on both transport demand and supply. When speaking about transport demand, previous studies have shown that adverse weather conditions lead to a significant change in modal distribution [10-12]. Also, adverse weather conditions increase the probability of a traffic accident $[13,14]$.

In relation to transport supply, there are papers which analyse in detail the impact of weather conditions on main traffic flow parameters such as traffic volume, speed, density, and capacity [5, 15-18]. Focus of the previously mentioned papers is the operational level, at intersection or road section. However, to enable quality input data at operational level, it may be important to assess impacts in a wider area, namely at macroscopic level. For example, in the first step, exploring whether rain will affect the redistribution of flows on the whole network using transport model and then in the second step focusing on managing these flows.

Transport models are commonly used to test and simulate the changes in transportation system [19, 20]. Most transport models do not include parameters that represent the impact of adverse weather conditions, in other words, models are typically developed for ideal weather conditions. Still, some authors [21] showed that transport models in combination with other techniques could represent a good tool for analysing impact of adverse weather condition and definition of adaptation measures.

This paper deals with implementation of the impact of rain in macroscopic transport models. Rain was chosen as the most frequent type of adverse weather in the researched area. Also, some research proved that rainfall has a great impact on the level-of-service of road network, especially in rush hour [22]. The impact of rain in the transport model was represented through calibrated volume-delay function as one of the most important input parameters for traffic assignment. Volume-delay function primarily describes changes in travel time for different values of volume/capacity ratio in under-saturated conditions. Various types of volume-delay functions have been developed. Some are mainly used in macro modelling [23-25], while others are used in micro modelling [26-31]. Regardless of the form, two compulsory parameters of a volume-delay function are (1) the volume/capacity ratio and (2) the free-flow travel time or free-flow speed. Volume-delay function needs calibration to represent the characteristics of speed (travel time) variations on different road categories $[32,33]$. The main criterion in traffic distribution models is usually minimisation of travel time and travel time for each route can be estimated based on the volume-delay function. Since rain has a direct impact on variations of street capacity and vehicle speed, it is important to calibrate volume-delay functions to the impacts of rain in order to get reliable travel times on alternative routes.

Main contributions of the paper are:

- Methodological approach to produce volume-delay functions for macroscopic models that include the impact of rain.

- Enabling macro-simulation transport models to be used as a generator of inputs for microsimulation models in rainy conditions.

- Giving arguments to support the inclusion of weather related analysis in common engineering practices.

The structure of the paper is as follows: Section 2 describes survey methodology. Section 3 summarises the results on the impacts of rain on street capacity, travel speed, and travel time. Section 4 is related to the volume-delay function calibration process, namely calibration methodology and experimental results of the calibration process. In Section 5, some conclusions are given.

\section{SURVEY METHODOLOGY}

This chapter presents the survey methodology for collecting data necessary to quantify the changes in street capacity, travel speed, and time.

Using highway sections is common in research of the adverse weather impact on road capacity and vehicle speed [34-36]. In contrast to the urban network, highway is characterised by uninterrupted flows allowing easier estimation and evaluation of external impacts such as adverse weather. In urban networks, street capacity is limited by intersection capacity and in signalised intersections, capacity is also affected by the green time ratio and the saturation flow rate. In previous research, the weather impact on urban network capacity is mainly quantified using saturation flow rate reduction [5, 37-39]. In general, the reduction of saturation flow rate under the impact of rain varied from $3 \%$ to $25 \%$.

A number of researchers address the impact of rain on vehicle speed. Some of the studies show that the rain intensity does not have a significant effect on travel speed reduction, i.e., the rain impact is constant regardless of the intensity $[6,40]$. On 
the other hand, some studies show different vehicle speed reductions for the same rain intensities. For example, Smith et al. (2003) showed operating speed reduction from $5-6.5 \%$ for rain intensity $<2.5 \mathrm{~mm} / \mathrm{h}$ while for the same rain intensities Jia et al. (2014) reported operation speed reduction 0.5$2 \%[40,41]$. On the contrary, some studies show that vehicle speed is strongly correlated to rain intensity [7]. These differences in conclusions could refer to different climate characteristics of the research areas and different driver behaviour in specific environments. Clearly, there is a necessity to conduct a local survey and it is not appropriate to apply foreign experiences in this field.

In line with previous conclusion, a comprehensive survey on the impact of rain on street network capacity and free-flow speed was carried out in the city of Belgrade, Serbia. Rain is the most common among adverse weather conditions that appear in the research area. Data on rain duration, frequen$\mathrm{cy}$, and intensity were collected from automatic meteorological stations at one-minute interval, in a four-year period. Rain intensities were categorised according to a specially developed methodology based on rain intensity and frequency of occurrence resulting in three rain categories [5]. The first rain category (RCI) is characterised by rain intensity ranging from 0 to $1 \mathrm{~mm} / \mathrm{h}$, while the second rain category (RCII) ranges from 1 to $5.9 \mathrm{~mm} / \mathrm{h}$. Although the consequences of extreme precipitation are a very complex and important problem [42], very low frequency of occurrence of high rain intensity (RCIII, over $5.9 \mathrm{~mm} / \mathrm{h}$ ) in research area resulted in its exclusion from further analysis.

The survey of the effects of rain on capacity was based on saturation flow rate values under IWC, and $\mathrm{RCI}$ and RCII rain categories. Saturation flow rate was determined using video recordings of successive vehicle headways in queue discharge process at signalised intersections. The intersections were selected to enable the analysis of the isolated impact of rain on the saturation flow rate, meaning that all other potential impacts were minimised. In order to ensure an unobstructed queue discharge process, the following preconditions had to be met:

- the intersection had a typical geometry;

- the queue from the upstream intersection did not have any impact on the entry flow of vehicles;

- the number of approach throughput lanes was equal to the number of exit lanes;
- there were no parking manoeuvres and no bus stops in the intersection area; and

- the share of commercial vehicles in the traffic flow was low.

The survey on the impact of rain on vehicle speed was based on travel speed and its variations for different rain categories. The impact of rain on free-flow speed was determined at one of the main urban arteries in Belgrade, Serbia. An appropriate survey section was chosen so that an isolated impact of rain could be recorded. The section additionally had to meet the following criteria:

- the length of the section should allow vehicles to reach the desired speed;

- no influence of vehicles in turning manoeuvres;

- absence of parking manoeuvres and bus stops; and

- low percentage of commercial vehicles in the traffic flow.

Free-flow speed profiles on the section in different weather conditions (IWC, RCI, and RCII) were obtained using the floating cars method with the help of GPS devices. The free-flow speed survey was carried out in the early morning hours under very low traffic volumes in order to minimise the impact of other vehicles in the traffic flow.

Since rain affects changes in free-flow speed (more or less significantly) and capacity, it is natural that there are also variations in travel time under different traffic volumes, i.e., volume/capacity ratios. Some previous research studies show correlation between rain intensity and increase of travel time. Depending on rain intensity, travel time increased in the range from $0.1 \%$ to $9 \%$ [7, 43-45]. In order to quantify the variation of travel time for different volume/capacity ratios and rain categories, the authors used the same street section as in the freeflow speed survey. Travel time was estimated using a plate recognition technique (Gyro-Stabilised Systems (GSS)) with cameras installed at the beginning and end of the section.

\section{SURVEY RESULTS}

Data on saturation flow rate in different rain intensities were gathered on four signalised intersections on a sample of over 1300 traffic signal cycles. Data were used to calculate the average reduction of saturation flow rate resulting in capacity reduction in the range of 3 to $6 \%$ for light rain (RCI) and in the range of 8 to $12 \%$ for heavy rain (RCII) [5]. 
When it comes to the analysis of the rain impact on free-flow speed for the total sample, speed profiles were determined. In order to ensure the quality of the recorded data, several indicators were recorded and analysed for each vehicle (Table 1).

The table shows only a part of the database. Changes in recorded speeds enable quantification of the impact of rain. The number of accelerations and decelerations and their intensity present the dif- ference in vehicle movement or driver behaviour for different rain intensities. The following figure shows an example of speed profiles (Figure 1).

The results show a different degree of free-flow speed reduction for different rain categories (RCI and RCII). It is interesting that the presence of rain had a higher impact on the free-flow speed than the rain intensity. The recorded free-flow speed reduction under the impact of RCI was $10.7 \%$, while for

Table 1 - Analysis of free-flow speed data

\begin{tabular}{|c|c|c|c|c|c|c|c|c|c|}
\hline 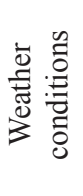 & $\begin{array}{l}\text { No. of } \\
\text { passing } \\
\text { vehicles }\end{array}$ & $\begin{array}{l}\text { Temporal } \\
\text { speed (start } \\
\text { of the } \\
\text { section) } \\
{[\mathrm{km} / \mathrm{h}]}\end{array}$ & $\begin{array}{c}\text { Temporal } \\
\text { speed } \\
\text { (end of the } \\
\text { section) } \\
{[\mathrm{km} / \mathrm{h}]}\end{array}$ & $\begin{array}{c}\text { Average } \\
\text { spatial } \\
\text { speed }\end{array}$ & $\begin{array}{l}\text { Standard } \\
\text { deviation }\end{array}$ & $\begin{array}{c}\text { No. of } \\
\text { acceleration }\end{array}$ & $\begin{array}{c}\text { Acceleration } \\
\text { range } \\
{\left[\mathrm{m} / \mathrm{s}^{2}\right]}\end{array}$ & $\begin{array}{l}\text { Number of } \\
\text { deceleration }\end{array}$ & $\begin{array}{l}\text { Deceleration } \\
\text { range } \\
{\left[\mathrm{m} / \mathrm{s}^{2}\right]}\end{array}$ \\
\hline \multirow{6}{*}{ IWC } & 1 & 53.6 & 54.2 & 54.1 & 2.26 & 5 & $0.02-0.3$ & 6 & $0.08-0.31$ \\
\hline & 2 & 51.6 & 53.3 & 52.3 & 2.18 & 4 & $0.09-0.22$ & 4 & $0.05-0.3$ \\
\hline & 3 & 52.9 & 56.2 & 54.6 & 1.68 & 5 & $0.07-0.21$ & 6 & $0.05-0.27$ \\
\hline & 4 & 49.2 & 52.9 & 52.7 & 1.24 & 5 & $0.06-0.17$ & 4 & $0.06-0.11$ \\
\hline & 5 & 52.9 & 54 & 53.4 & 0.94 & 4 & $0.08-0.17$ & 5 & $0.01-0.13$ \\
\hline & \multicolumn{9}{|c|}{$\ldots$} \\
\hline \multirow{6}{*}{ RCI } & 1 & 52.1 & 50.6 & 50.9 & 0.75 & 4 & $0.09-0.14$ & 4 & $0.05-0.17$ \\
\hline & 2 & 48.5 & 46.9 & 48.1 & 1.37 & 8 & $0.06-0.28$ & 7 & $0.03-0.22$ \\
\hline & 3 & 47.4 & 44.7 & 45.8 & 0.9 & 7 & $0.03-0.14$ & 8 & $0.01-0.25$ \\
\hline & 4 & 51.3 & 53.7 & 52 & 0.79 & 5 & $0.08-0.24$ & 4 & $0.08-0.2$ \\
\hline & 5 & 45.3 & 47.9 & 45.6 & 1.45 & 8 & $0.03-0.22$ & 7 & $0.06-0.36$ \\
\hline & \multicolumn{9}{|c|}{$\ldots$} \\
\hline \multirow{5}{*}{ RCII } & 1 & 46.5 & 48.2 & 46.6 & 0.89 & 9 & $0.06-0.61$ & 8 & $0.03-0.44$ \\
\hline & 2 & 45.1 & 46.7 & 47.6 & 1.04 & 7 & $0.06-0.43$ & 8 & $0.04-0.63$ \\
\hline & 3 & 44.8 & 44.3 & 44.8 & 0.79 & 8 & $0.08-0.33$ & 8 & $0.12-0.35$ \\
\hline & 4 & 46 & 46.8 & 46.3 & 0.99 & 7 & $0.1-0.33$ & 7 & $0.03-0.28$ \\
\hline & 5 & 44.4 & 48.6 & 45.3 & 0.92 & 5 & $0.07-0.36$ & 5 & $0.06-0.18$ \\
\hline
\end{tabular}

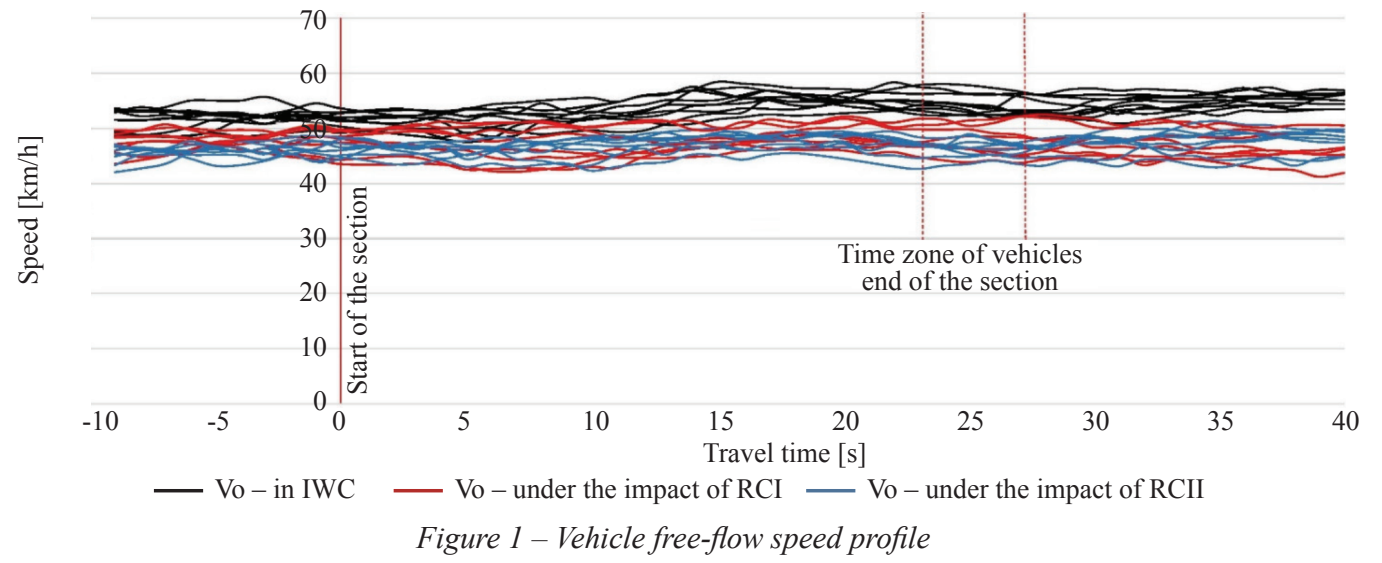


the RCII the reduction was $12.8 \%$. The percentage of reduction is significant, but it should be kept in mind that the survey was carried out in an urban environment with the lower vehicle speeds comparing to speeds on highway.

Empirical data of the vehicles travel time under different weather conditions is present on the following figure (Figure 2).

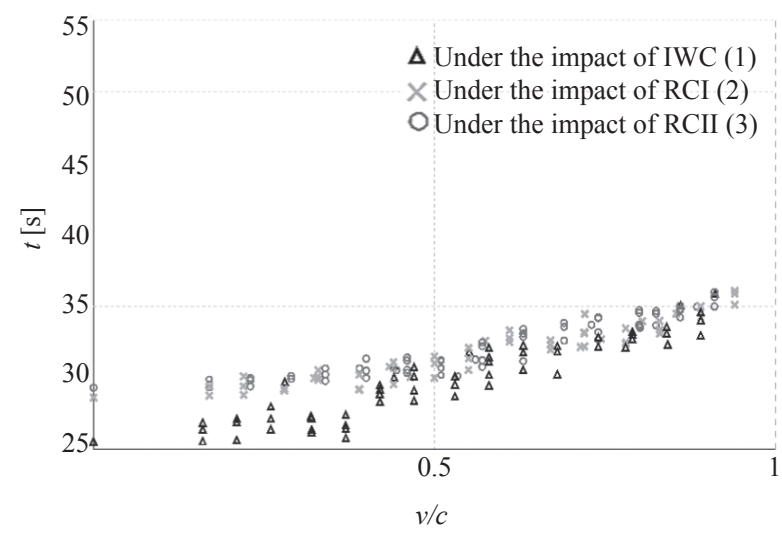

Figure 2 - Travel time under different rain category impacts and different volume-capacity ratio

The highest recorded value of volume/capacity ratio was 0.94 . Dispersion of travel time values in different weather conditions decreases with the increase of volume/capacity ratio, i.e., travel time during rain will converge toward travel time in ideal weather conditions for higher values of the volume/ capacity ratio. With the increase of the volume/capacity ratio, the impact of interaction between vehicles is increasing and becomes predominant in relation to other potential impacts on traffic flow characteristics, in this case of the rain impact.

\section{VOLUME-DELAY FUNCTION CALIBRATION}

In this chapter the phases of the methodology of volume-delay function calibration are presented. Also, experimental results of the application of methodology are shown.

\subsection{Calibration methodology}

The focus of this paper was not to find a volume-delay function that best fits the data (IWC, RCI, and RCII), but rather to develop a methodology to implement the rain impact into the function for under-saturated and over-saturated traffic conditions.
Calibration methodology consists of several phases:

1) In the first phase, it is important to define rain categories which will be used to analyse the impact of rain. The choice depends on geographical location and climate characteristics of the survey area.

2) In this phase it is necessary to determine a volume-delay function for IWC. Determination of volume-delay function is based on empirical data. The choice of the volume-delay function type is qualified by the scope of the model and the level of details. It is important to note that the proposed methodology is applicable regardless of the volume-delay function type.

3) Defining the volume-delay function for different rain categories. It is important to note that obtaining empirical data for the over-saturated part of the function is unrealistic. Even though this part of the volume-delay function does not represent real traffic conditions, it is very important for traffic assignment procedure in the transport model. In the initial iterations of traffic assignment, traffic volumes on certain links could be higher than the capacity (over-saturated conditions). In that case, the flow distribution depends on the form of the volume-delay function for over-saturated conditions $(v / c>1)$ as conditions that force travellers to change their route [25].

The authors decided to demonstrate the calibration methodology on the BPR volume-delay function. The BPR function was primarily selected because of its simplicity reflected in a small number of variables. The form of the BPR function is as follows [23]:

$t=t_{0}\left(1+\alpha\left(\frac{v}{c}\right)^{\beta}\right.$

$t \quad$ - travel time;

$t_{0} \quad$ - free-flow travel time;

$v$ - traffic volume,

$c$ - capacity;

$\alpha, \beta$ - coefficients

In order to define this function, it is necessary to determine $t_{0}, c$, and coefficients $\alpha$ and $\beta$. Values of $t_{0}$ and $c$ in IWC and under the influence of $\mathrm{RCI}$ and RCII can be determined from previously collected data.

In order to determine the coefficients $\alpha$ and $\beta$ based on the empirical data, function approximation (curve fitting) must be performed. The approximation involves transformation of the initial form of the function: 
$t=t_{0}\left(1+\alpha\left(\frac{q}{c}\right)^{\beta}\right.$

$\frac{t-t_{0}}{t_{0}}=\alpha\left(\frac{q}{c}\right)^{\beta}$

$\frac{t-t_{0}}{t_{0}}=y ; \quad \frac{q}{c}=x$

The final, simplified form of the function was:

$y=\alpha x^{\beta}$

Since this is a power function, the transformation could imply linearisation which could give the following form of the function:

$\log (y)=\beta \log (x)+\log (\alpha)$

Curve fitting involves the search for optimal values of coefficients ( $\alpha$ and $\beta$ ) using empirical data and known values for $t_{0}$ and $c$ for each of the analysed weather conditions. The default values of $\alpha$ and $\beta$ in the BPR function are set to 0.15 and 4.0, respectively. However, there are papers where values of these coefficients differ [33, 46-48].

The Authors propose generating a set of solutions in order to find an optimal solution, best values of the $\alpha$ and $\beta$ coefficients using ranges defined in the literature. Values of the $\alpha$ coefficient were explored in the range from 0.01 to 5 , and values of $\beta$ coefficient in the range from 0.01 to 8 . A coefficient offset value of 0.001 is proposed.

$0.01<\alpha<5 \quad$ with 0.001 step

$0.01<\alpha<8$ with 0.001 step

Curve fitting can be executed in Mat Lab using the least squares optimisation. From the set of possible solutions, the best ones are adopted.

4) Survey data cover only the under-saturated conditions. Since it was also necessary to define the volume-delay function for over-saturated conditions, it is proposed to use the IWC curve to approximate this part of the RC curve. By analysing the survey data (Figure 2) and dispersion of travel time values recorded in different weather conditions, there is a high probability that the forecast of the RC curve position in over-saturated traffic conditions will show a shorter travel time $(\Delta t)$ than the curve generated in the IWC (Figure 3).

The Authors assumed that in cases of high values of volume/capacity ratio, rain cannot significantly change the main traffic flow characteristics which implies that value of $\Delta t$ in over/saturated traffic conditions tends to be close to zero (Figure 3).

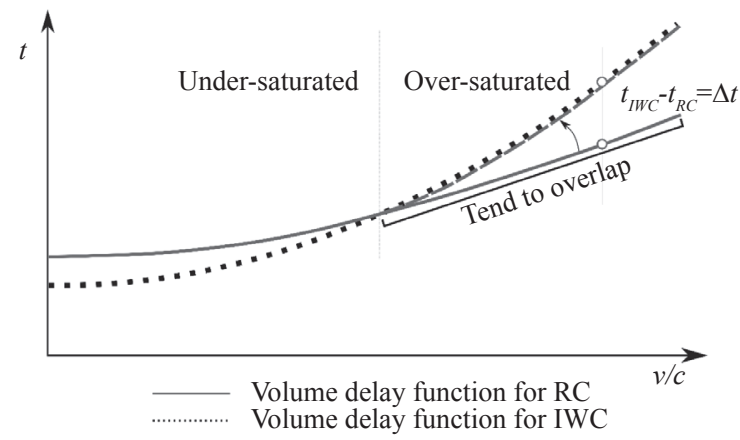

Figure 3 - Overlap of the RC and IWC curves for oversaturated traffic conditions

A maximum value of $v / c$ also needs to be set. In the proposed methodology, the limit was set to 1.4 , representing even wider range than in the Akcelik's paper (1991), which represents one of the most important papers related to volume-delay functions, where a maximum $v / c=1.2$ was used [49].

5) Bearing in mind that forcing the overlap of functions (IWC and RC) for over-saturated conditions could lead to changes of the curve position in under-saturated traffic conditions, it is necessary to check deviations in relation to the initial function using some statistical measures, like RMSE and MAE.

$R M S E=\sqrt{\frac{1}{N} \sum_{i=1}^{N}\left(x_{i}-w_{i}\right)^{2}}$

$M A E=\frac{1}{N} \sum_{i=1}^{N}\left|x_{i}-w_{i}\right|$

$x_{i} \quad-$ value of travel time for certain value of $v / c$ for volume-delay function under the RCI and RCII

$w_{i} \quad$ - value of travel time for the same value of $v / c$ for the calibrated volume-delay function under the RCI and RCII

$N \quad$ - number of ED per rain category

RMSE - square root of the average of squared deviations and it gives a relatively high weight to large errors

$M A E$ - linear so that all deviations between predicted values and empirical values have an equal weight.

\subsection{Experimental results}

The first phase, related to determining different rain categories, was already presented in section 2 and it is based on the Authors' previous research [5]. The results of phases 2 and 3 are three volume-delay functions: IWC, RCI, and RCII (Figure 4) 


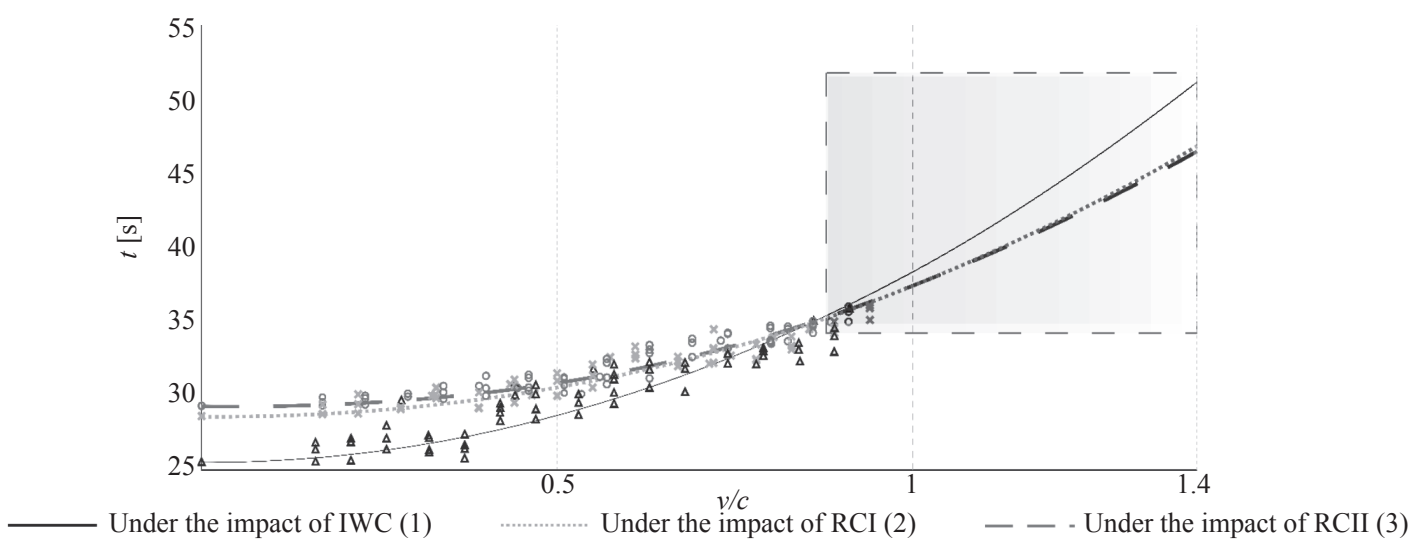

Figure 4-Approximated BPR curves based on empirical data

Table 2 - Generated coefficients of the BPR curves

\begin{tabular}{||l|c|c|}
\hline \multicolumn{1}{|c|}{ Weather conditions } & $\alpha$ & $\beta$ \\
\hline \hline IWC (1) & 0.505 & 2.049 \\
\hline RCI (2) & 0.307 & 2.189 \\
\hline RCII (3) & 0.278 & 2.247 \\
\hline
\end{tabular}

Calculated values of $\alpha$ and $\beta$ coefficients are presented in Table 2.

Phase 4 is based on the graph (Figure 4) and it shows that the approximated curves intersect at points with the following values of the volume/ capacity ratio: 0.85 (1 and 2), 0.88 (1 and 3), and 1.04 (2 and 3). After the intersection points, curves 2 and 3 (RCI and RCII) go below curve 1 (IWC) (rectangle in Figure 4) which is cause for calibration. Curve that fits the best was produced by using Mat Lab and the least squares optimisation. The necessary input data were reduction of capacity and free flow speed in a specific rain category and volume/capacity ratio which indicate the start convergence point between the RC curves and the curve in IWC.
The primal assumption was that typically the values of volume/capacity ratio above $85 \%$ present a high degree of saturation [50]. The aim was to define a starting point ( $v / c$ value) of convergence. The set of possible starting points covered the range between $v / c=0.85$ and $v / c=1$, with a step of 0.05 . The quality of calibration was measured using the least square method to strive minimal deviations of the calibrated curve in relation to the initial curve (in range of empirical data), i.e., in this case in the range of $v / c \leq 0.94$.

Calibrated volume-delay functions under the rain impact are presented in Figure 5.

Table 3 presents calibrated values of the $\alpha$ and $\beta$ coefficients for the impact of RCI and RCII.

In the final phase 5 , it was necessary to examine the differences between the initially obtained volume-delay functions under the rain impact and the

Table 3 - Values of $\alpha$ and $\beta$ coefficients for calibrated curves

\begin{tabular}{|l|c|c||}
\hline \hline Weather conditions & $\alpha$ & $\beta$ \\
\hline \hline RCI $(2$ cal $)$ & 0.338 & 2.549 \\
\hline RCII $(3$ cal $)$ & 0.306 & 2.694 \\
\hline
\end{tabular}

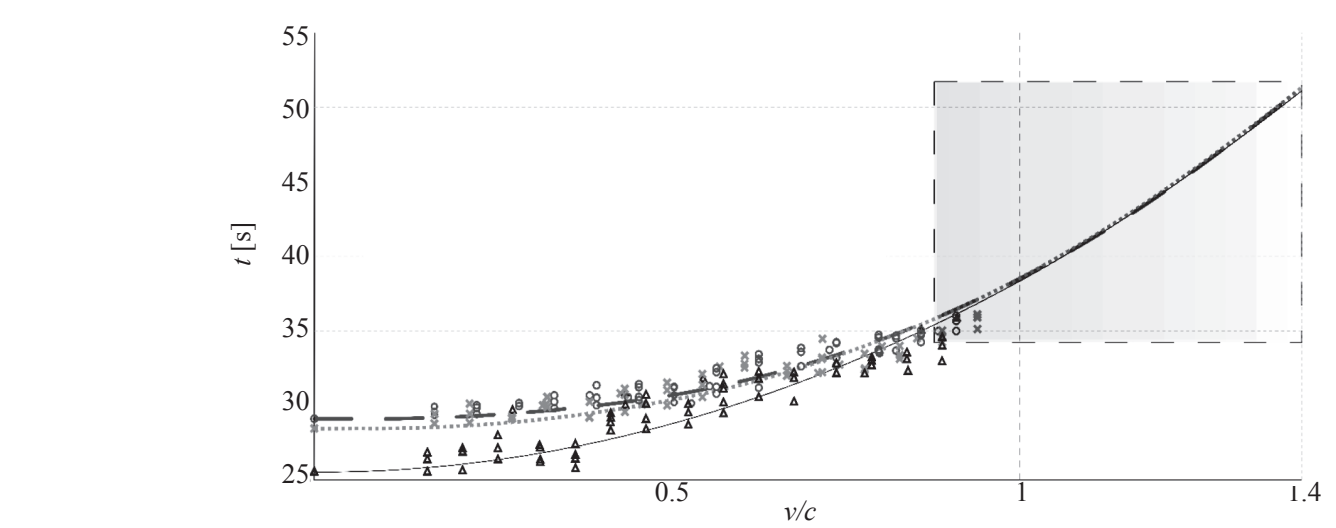

— Under the impact of IWC (1)

Calibrated function - impact of RCI (2 cal)

- - Calibrated function - impact of RCII (3 cal)

Figure 5 - Calibrated BPR curves 
calibrated volume-delay functions. This difference was examined only for the empirical data domain $(v / c \leq 0.94)$, using two statistical measures: the root mean squared error (RMSE) and the mean absolute error (MAE). The differences were rather small and indicate a high level of similarity between the initially defined curves and the calibrated curves (Table 4).

Table 4-RMSE and MAE: differences between calibrated curves and initially defined BPR curves

\begin{tabular}{||l|c|c|}
\cline { 2 - 3 } \multicolumn{1}{c|}{} & RMSE (sec) & MAE (sec) \\
\hline RCI cal / RCI & 0.16 & 0.13 \\
\hline RCII cal / RCII & 0.11 & 0.07 \\
\hline
\end{tabular}

The results support the proposed methodology for calibrating the volume-delay function and implementing the impact of rain in traffic assignment procedure.

\section{CONCLUSION}

Traffic assignment procedures in transport modelling are commonly based on travel time, with the volume-delay functions being one of the most important inputs. Volume-delay functions are generally set for ideal weather conditions and such an approach does not enable a realistic traffic assignment in rainy conditions.

The focus of this paper is on implementation of the impact of rain in volume-delay function. The impact of different rain categories on the basic parameters of volume-delay functions was quantified based on the research results. It has been determined that the occurrence of rain affects the reduction of capacity in the range of $3-12 \%$, depending on the rain category. The average values of free-flow speed reduction are $10.7 \%$ for RCI and $12.8 \%$ for RCII. It was concluded that the free-flow speed was affected more by the rain occurrence than by the rain intensity. Moreover, it was concluded that travel time under the influence of rain converged with travel time values under ideal weather conditions for a high value of saturation degree. With the increase of saturation degree impact of the interaction between vehicles becomes dominant in relation to other potential impacts on traffic flow characteristics.

The results of the research were used to develop a methodology for calibrating the volume-delay function to the impact of rain. The methodology was applied to the BPR volume-delay but it can also be applied to any other type of volume-delay functions. Given that the survey data for creating the volume-delay function are mostly related to under saturated conditions, the presented methodology also enables implementation of the rain impact in the over-saturated part of the volume-delay function.

In order to create a more resilient and robust transportation system, it is important to implement the rain impact in the existing modelling procedures. It allows testing the transportation system supply sensitivity on that impact and in parallel provides better input data for traffic management purposes.

Further research on this topic will be directed towards the analyses of other kinds of adverse weather impacts on the transportation system, such as snow and fog. In the next phase of the research, it is planned to apply this methodology in a real transport model to enable quantifications of the rain impact on the traffic characteristics. In addition, future efforts will concentrate on analysing the feasibility of implementing specific traffic management measures to mitigate adverse weather impacts creating a weather responsive decision support system for traffic managers.

\section{ACKNOWLEDGMENT}

This work was supported by the Ministry of Science and Technological Development of the Republic of Serbia.

\section{Docent, Dr Ivan IVANOVIĆ ${ }^{1}$ \\ E-mail: i.ivanovic@sf.bg.ac.rs \\ Prof. Dr Nikola ČELAR ${ }^{1}$ \\ E-mail: n.celar@sf.bg.ac.rs \\ Prof. Dr Vladimir ĐORIĆ \\ E-mail: v.djoric@sf.bg.ac.rs \\ Docent, Dr Dragana PETROVIĆ ${ }^{1}$ \\ E-mail: dragana.petrovic@sf.bg.ac.rs \\ ${ }^{1}$ Univerzitet u Beogradu, Saobraćajni fakultet \\ Vojvode Stepe 305, 11000, Beograd, Srbija}

\section{MODELIRANJE UTICAJA KIŠE U PROCEDURI SAOBRAĆAJNOG OPTEREĆENJA}

\section{REZIME}

Efikasnost transportnog sistema je pod uticajem vremenskih prilika. Da bi se pripremile odgovarajuće mere u cilju ublažavanja uticaja nepovoljnih vremenskih prilika neophodno je ukljuciti ih u analizu transportnog sistema. Transportni modeli se često koriste u različitim transportnim analizama i prognozama budućih karakteristika transportnog sistema. Ovaj rad je fokusiran na implementaciju uticaja kiše u modeliranje, posebno 
u procedure opterećenja ulične mreže u makroskopskom transportnom modelu. Ovaj aspekt modeliranja je posebno važan jer ukazuje na delove mreže na kojima dolazi do značajnog povećanja odnosa protok/kapacitet što predstavlja dobar ulazni podatak u definisanju mera za ublažavanje negativnih posledica. Transportni modeli $u$ standardnim procedurama uglavnom ne uzimaju u obzir uticaj vremenskih prilika. Rad predstavlja metodologiju za kalibraciju funkcije vremena putovanja sa ciljem unapređenja procesa saobraćajnog opterećenja u uslovima kiše. Uticaj različitih kategorija kiše na kapacitet $i$ brzinu slobodnog toka je kvantifikovan i implementiran $u$ funkciju vremena putovanja. Posebna pažnja je posvećena kalibraciji funkcije vremena putovanja u uslovima zasićenog saobraćajnog toka. Metodologija kalibracije je primenljiva na različite tipove funkcija vremena putovanja i predstavlja adekvatan pristup implementaciji uticaja vremenskih prilika u inženjersku praksu.

\section{KLJUČNE REČI}

uticaj kiše; funkcija vremena putovanja; transportni model; saobraćajno opterećenje.

\section{REFERENCES}

[1] Pregnolato $M$, et al. Assessing urban strategies for reducing the impacts of extreme weather on infrastructure networks. Royal Society Open Science. 2007;3(5). doi: 10.1098/rsos.160023.

[2] Ogryzek M, Adamska-Kmieć D, Klimach A. Sustainable transport: An efficient transportation network-case study. Sustainability. 2020;12(19): 1-14. doi: 10.3390/ su12198274.

[3] Saneinejad S, Roorda MJ, Kennedy C. Modelling the impact of weather conditions on active transportation travel behaviour. Transportation Research Part D: Transport and Environment. 2012;17(2): 129-137. doi: 10.1016/ j.trd.2011.09.005.

[4] Schwanen T. Transport geography, climate change and space: opportunity for new thinking. Journal of Transport Geography. 2019;81(April): 102530. doi: 10.1016/ j.jtrangeo.2019.102530.

[5] Ivanović I, Jović J. Sensitivity of street network capacity under the rain impact: Case study of Belgrade. Transport. 2018;33(2): 470-477. doi: 10.3846/ 16484142.2017.1283532.

[6] Kyte M, Khatib Z, Shannon P, Kitchener F. Effect of weather on free-flow speed. Journal of the Transportation Research Board. 2001;1776(1): 60-68. doi: 10.3141/1776-08.

[7] Tsapakis I, Cheng T, Bolbol A. Impact of weather conditions on macroscopic urban travel times. Journal of Transport Geography. 2013;28 204-211. doi: 10.1016/ j.jtrangeo.2012.11.003.

[8] Calvert SC, Snelder M. A methodology for road traffic resilience analysis and review of related concepts. Transportmetrica A: Transport Science. 2018;14(1-2): 130154. doi: 10.1080/23249935.2017.1363315.

[9] Quinn AD, et al. Adaptation becoming business as usual: A framework for climate-change-ready transport infra- structure. Infrastructures. 2018;3(2). doi: 10.3390/infrastructures3020010.

[10] Tao S, Corcoran J, Rowe F, Hickman M. To travel or not to travel: 'Weather' is the question. Modelling the effect of local weather conditions on bus ridership. Transportation Research Part C: Emerging Technologies. 2018;86(November 2017): 147-167. doi: 10.1016/j. trc.2017.11.005.

[11] Wei M, Corcoran J, Sigler T, Liu Y. Modeling the influence of weather on transit ridership: A case study from Brisbane, Australia. Transportation Research Record. 2018;2672(8): 505-510. doi: 10.1177/0361198118777078.

[12] Petrović D, Ivanović I, Đorić V, Jović J. Impact of weather conditions on travel demand - the most common research methods and applied models. Promet - Traffic\&Transportation. 2020;32(5): 711-725. doi: 10.7307/ ptt.v32i5.3499.

[13] Malin F, Norros I, Innamaa S. Accident risk of road and weather conditions on different road types. Accident Analysis and Prevention. 2019;122(October 2018): 181188. doi: 10.1016/j.aap.2018.10.014.

[14] Theofilatos A, Yannis G. A review of the effect of traffic and weather characteristics on road safety. Accident Analysis and Prevention. 2014;72: 244-256. doi: 10.1016/j.aap.2014.06.017.

[15] Hooper E, Chapman L, Quinn A. The impact of precipitation on speed-flow relationships along a UK motorway corridor. Theoretical and Applied Climatology. 2013. doi: 10.1007/s00704-013-0999-5.

[16] Kidando E, et al. Applying probabilistic model to quantify influence of rainy weather on stochastic and dynamic transition of traffic conditions. Journal of Transportation Engineering, Part A: Systems. 2019;145(5).

[17] Shang P, Li R, Liu Z, Li X. Inclement weather impacts on urban traffic conditions. CICTP2015; 2015. p. 22132227. doi: 10.1061/9780784479292.fm.

[18] Zhang W, Li R, Shang P, Liu H. Impact analysis of rainfall on traffic flow characteristics in Beijing. International Journal of Intelligent Transportation Systems Research. 2019;17(2): 150-160. doi: 10.1007/s13177-018-0162-x.

[19] Anda C, Erath A, Fourie PJ. Transport modelling in the age of big data. International Journal of Urban Sciences. 2017;21(October): 19-42. doi: 10.1080/12265934.2017.1281150.

[20] Jović J, Dorić V. Traffic and environmental street network modelling: Belgrade case study. Transport. 2010;25(2). doi: 10.3846/transport.2010.19.

[21] Snelder M, Calvert S. Quantifying the impact of adverse weather conditions on road network performance. European Journal of Transport and Infrastructure Research. 2016;16(1): 128-149. doi: 10.18757/ ejtir.2016.16.1.3118.

[22] $\mathrm{Xu} \mathrm{F}$, et al. Assessing the impact of rainfall on traffic operation of urban road network. Proceedings from the $13^{\text {th }}$ COTA International Conference of Transportation Professionals (CICTP2013); 2013. p. 96, 82-89. doi: 10.1016/j.sbspro.2013.08.

[23] Bureau of Public Roads. Traffic assignment manual for application with a large, high speed computer. Washington, D.C.: U.S. Dept. of Commerce, Bureau of Public 
Roads, Office of Planning, Urban Planning Division; 1964.

[24] Haider M, Spurr T. The design and development of largescale traffic assignment models using geographic information systems. Transportation Research Board $85^{\text {th }}$ Annual Meeting, 22-26 Jan. 2006, DC Washington; 2006. p. 24.

[25] Spiess H. Technical note - conical volume-delay functions. Transportation Science. 1990;24(2): 153-158. doi: 10.1287/trsc.24.2.153.

[26] Akcelik R. Travel time functions for transport planning purposes: Davidson's function, its time-dependent form and an alternative travel time function. Australian Road Research. 2000;21(December): 49-59.

[27] Cheu RL, Lee DH, Xie C. An arterial speed estimation model fusing data from stationary and mobile sensors. Intelligent Transportation Systems, Proceedings. IEEE; 2001. p. 573-578. doi: 10.1109/ITSC.2001.948723.

[28] Dowling R, Skabardonis A. Urban arterial speed-flow equations for travel demand models. A Transportation Research Board Conference, Innovations in Travel Demand Modeling Conference, 21-23 May, Austin, Texas; 2008. p. 109-113.

[29] Lu C, Zhao F, Hadi M. A travel time estimation method for planning models considering signalized intersections. ICCTP Integrated Transportation Systems: Green, Intelligent, Reliable; 2010. p. 1993-2000. doi: 10.1061/41127(382)215.

[30] Singh R, Dowling R. Improved speed-flow relationships: Application to transportation planning models. $7^{\text {th }}$ TRB Conference on the Application of Transportation Planning Methods. 1999. p. 340-349. http://docs. trb.org/00939750.pdf.

[31] Tisato P. Suggestions for an improved Davidson travel time function. Australian Road Research. 1991;21(2): 85-110. http://arrbknowledge.com.

[32] Lum KM, Fan HSL, Lam SH, Olszewski P. Speedflow modeling of arterial roads in Singapore. Journal of Transportation Engineering. 1998;124(3): 213-222. doi: 10.1061/(ASCE)0733-947X(1998)124:3(213).

[33] Neuhold R, Fellendorf M. Volume delay functions based on stochastic capacity. Journal of the Transportation Research Board. 2014;2421(1): 93-102. doi: 10.3141/2421-11.

[34] Agarwal M, Maze TH, Souleyrette R. Impacts of weather on urban freeway traffic flow characteristics and facility capacity. Proceedings of the 2005 Mid-Continent Transportation Research Symposium; 2005. p. 14. http://www.ctre.iastate.edu/pubs/midcon2005/\#weather.

[35] Angel ML, Sando T, Chimba D, Kwigizile V. Effects of rain on traffic operations on Florida freeways. Transportation Research Record. 2014;2440(2440): 51-59. doi: 10.3141/2440-07.

[36] Van Stralen W, Calvert S, Molin EJE. The influence of adverse weather conditions on the probability of congestion on Dutch motorways. European Journal of Transport \& Infrastructure Research. 2015:15(4): 482500. doi: 10.18757/ejtir.2015.15.4.3093.
[37] Asamer J, Van Zuylen H. Saturation flow under adverse weather conditions. Journal of the Transportation Research Board. 2012;2258: 103-109. doi: 10.3141/225813.

[38] Chodur J, Ostrowski K, Tracz M. Impact of saturation flow changes on performance of traffic lanes at signalised intersections. Procedia - Social and Behavioral Sciences, $6^{\text {th }}$ International Symposium on Highway Capacity and Quality of Service; 2011. p. 600-611.

[39] Sun H, Yang J, Wang L, Li L. Saturation flow rate and start-up lost time of dual-left lanes at signalized intersection in rainy weather condition. Proceedings from the $13^{\text {th }}$ COTA International Conference of Transportation Professionals (CICTP2013); 2013. p. 96, 270-279.

[40] Smith BL, et al. An investigation into the impact of rainfall on freeway traffic flow. Transportation Research Board 83 ${ }^{\text {rd }}$ Annual Meeting; 2004.

[41] Jia Y, Du Y, Wu J. Impacts of rainfall weather on urban traffic in Beijing: Analysis and modeling. Transportation Research Board 94 $4^{\text {th }}$ Annual Meeting, 11-15 Jan. 2015, Washington DC, US; 2015. p. 14.

[42] Pregnolato M, Ford A, Wilkinson SM, Dawson RJ. The impact of flooding on road transport: A depth-disruption function. Transportation Research Part D: Transport and Environment. 2017;55: 67-81. doi: 10.1016/j. $\operatorname{trd}$.2017.06.020.

[43] Lam WHK, Tam ML, Cao X, Li X. Modeling the effects of rainfall intensity on traffic speed, flow, and density relationships for urban roads. Journal of Transportation Engineering. 2013;139(7): 758-770. doi: 10.1061/ (ASCE)TE.1943-5436.0000544.

[44] Mitsakis E, Stamos I, Diakakis M, Salanova Grau JM. Impacts of high-intensity storms on urban transportation: Applying traffic flow control methodologies for quantifying the effects. International Journal of Environmental Science and Technology. 2014;11(8): 2145-2154.

[45] Stamos I, Salanova Grau JM, Mitsakis E, Aifadopoulou G. Modeling effects of precipitation on vehicle speed: Floating car data approach. Transportation Research Record. 2016;2551: 100-110. doi: 10.3141/2551-12.

[46] Cambridge Systematics. Travel Demand Forecasting: Parameters and Techniques. Washington, D.C. NCHRP Report 716, 2013.

[47] De Sousa JF, Rossi R. Computer-based modelling and optimization in transportation. Advances in Intelligent Systems and Computing. 2014;262: 293-306. doi: 10.1007/978-3-319-04630-3.

[48] Horowitz A. Delay-volume relations for travel forecasting: Based on the 1985 highway capacity manual. Federal Highway Administration U.S. Department of Transportation; 1991. https://www.fhwa.dot.gov/planning/ tmip/publications/other_reports/delay_volume_relati.

[49] Akcelik R. Travel time functions for transport planning purposes: Davidson's function, its time dependent form and alternative travel time function. Australian Road Research. 1991;21(3): 49-59. http://arrbknowledge.com.

[50] Highway capacity manual. Transportation Research Board; 2010. 